\title{
Bedside Head Impulse Test: A Useful Tool for Patients With Sensory Ataxia
}

Stefano Tozza, MD, Andrea Cortese, MD, PhD, Aniello lovino, MD, Marcello Esposito, MD, PhD, Natalia Dominik, MSc, Rosa lodice, MD, and Fiore Manganelli, MD

Neurol Genet 2021;7:e541. doi:10.1212/NXG.0000000000000541

Figure Brain MRI of CANVAS Patient

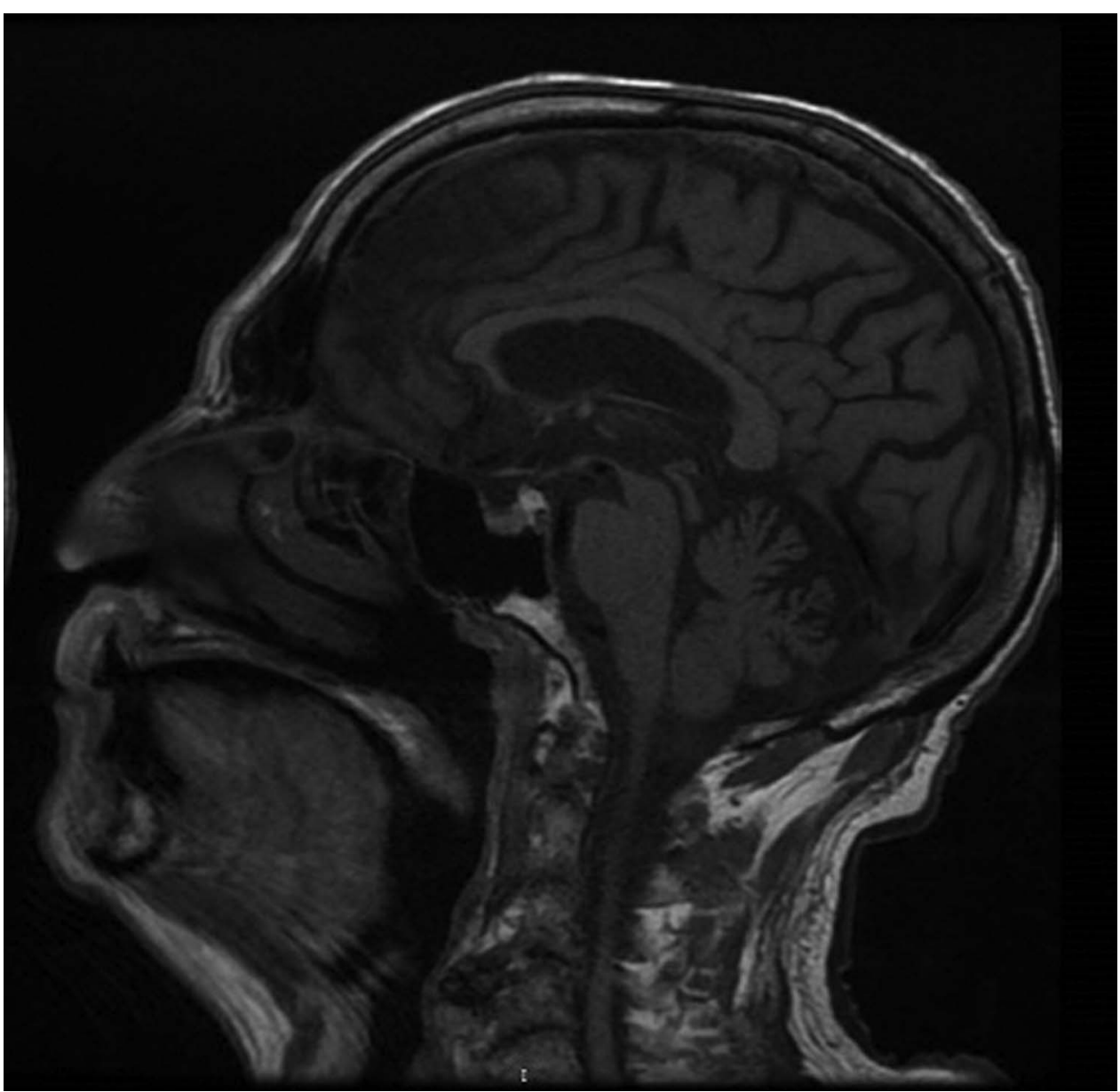

Brain MR T1-weighted, midsagittal image shows cerebellar vermian atrophy. CANVAS = cerebellar ataxia, neuropathy and vestibular areflexia syndrome.

\section{Case Summary}

An 85-year-old man suffered from a 20-year history of idiopathic sensory neuronopathy (figure). Neurologic examination was characterized by severe sensory ataxia needing bilateral support
Correspondence

Dr. Tozza

ste.tozza@gmail.com
MORE ONLINE

\section{O Video}

From the Department of Neuroscience, Reproductive and Odontostomatology Science (S.T., A.I., M.E., R.I., and F.M.), University of Naples Federico II, Italy; MRC Centre for Neuromuscular Diseases (A.C. and N.D.), Department of Neuromuscular Diseases, National Hospital for Neurology and Neurosurgery, UCL Queen Square Institute of Neurology, United Kingdom; and Department of Brain and Behavioral Sciences, University of Pavia, Italy.

Go to Neurology.org/NG for full disclosures. Funding information is provided at the end of the article.

The Article Processing charge was funded by the Department of Neuroscience, Reproductive and Odontostomatology Science, University of Naples Federico II, Naples, Italy.

This is an open access article distributed under the terms of the Creative Commons Attribution-NonCommercial-NoDerivatives License 4.0 (CC BY-NC-ND), which permits downloading and sharing the work provided it is properly cited. The work cannot be changed in any way or used commercially without permission from the journal. 
during walking, subtle dysarthria, and reduced sensation for all modalities. Bedside head impulse test (HIT) revealed vestibular areflexia (video 1), arising suspicion of cerebellar ataxia, neuropathy, and vestibular areflexia syndrome (CANVAS), then confirmed by the presence of biallelic expansion in RFC1 gene. ${ }^{1}$ Clinical sensory involvement can be the only manifestation in some CANVAS patients, ${ }^{2}$ and HIT, although overlooked in neurologic examination, should be performed in all patients with sensory ataxia to raise suspicion of CANVAS.

\section{Study Funding}

A. Cortese thanks Medical Research Council (MR/T001712/ 1), Fondazione CARIPLO (2019-1836), Italian Ministry of Health Ricerca Corrente 2018-2019 and 2020 and the Inherited Neuropathy Consortium (INC) for grant support.

\section{Disclosure}

The authors declare no financial or other conflicts of interest. Go to Neurology.org/NG for full disclosures.

\section{Publication History}

Received by Neurology: Genetics October 2, 2020. Accepted in final form October 29, 2020.

\section{Appendix Authors}

\begin{tabular}{lll}
\hline Name & Location & Contribution \\
\hline $\begin{array}{l}\text { Stefano } \\
\text { Tozza, MD }\end{array}$ & $\begin{array}{l}\text { Department of } \\
\text { Neuroscience, } \\
\text { Reproductive and } \\
\text { Odontostomatology } \\
\text { Science, University of }\end{array}$ & $\begin{array}{l}\text { Design and conceptualized } \\
\text { study, acquisition and } \\
\text { analyzed the data, and } \\
\text { drafted the manuscript for } \\
\text { intellectual content }\end{array}$ \\
& Naples Federico II, Italy & \\
\hline Andrea & MRC Center for & Analyzed the data and \\
Cortese, MD & Neuromuscular Diseases, & revised the manuscript for \\
& intellectual content \\
& Nepartment of & \\
& National Hospital for & \\
& Neurology and & \\
& Neurosurgery, UCL Queen & \\
& Square Institute of & \\
& Neurology, United Kingdom; & \\
& Department of Brain and \\
Behavioral Sciences, & \\
& University of Pavia, Italy & \\
&
\end{tabular}

Appendix (continued)

\begin{tabular}{|c|c|c|}
\hline Name & Location & Contribution \\
\hline $\begin{array}{l}\text { Aniello } \\
\text { lovino, MD }\end{array}$ & $\begin{array}{l}\text { Department of } \\
\text { Neuroscience, } \\
\text { Reproductive and } \\
\text { Odontostomatology } \\
\text { Science, University of } \\
\text { Naples Federico II, } \\
\text { Italy }\end{array}$ & $\begin{array}{l}\text { Revised the manuscript for } \\
\text { intellectual content }\end{array}$ \\
\hline $\begin{array}{l}\text { Marcello } \\
\text { Esposito, } \\
\text { MD, PhD }\end{array}$ & $\begin{array}{l}\text { Department of } \\
\text { Neuroscience, } \\
\text { Reproductive and } \\
\text { Odontostomatology } \\
\text { Science, University of } \\
\text { Naples Federico II, } \\
\text { Italy }\end{array}$ & $\begin{array}{l}\text { Revised the manuscript for } \\
\text { intellectual content }\end{array}$ \\
\hline $\begin{array}{l}\text { Natalia } \\
\text { Dominik }\end{array}$ & $\begin{array}{l}\text { MRC Center for } \\
\text { Neuromuscular Diseases, } \\
\text { Department of } \\
\text { Neuromuscular Diseases, } \\
\text { National Hospital for } \\
\text { Neurology and } \\
\text { Neurosurgery, UCL Queen } \\
\text { Square Institute of } \\
\text { Neurology, United } \\
\text { Kingdom }\end{array}$ & $\begin{array}{l}\text { Analyzed the data and } \\
\text { revised the manuscript for } \\
\text { intellectual content }\end{array}$ \\
\hline $\begin{array}{l}\text { Rosa lodice, } \\
\text { MD }\end{array}$ & $\begin{array}{l}\text { Department of } \\
\text { Neuroscience, } \\
\text { Reproductive and } \\
\text { Odontostomatology } \\
\text { Science, University of } \\
\text { Naples Federico II, } \\
\text { Italy }\end{array}$ & $\begin{array}{l}\text { Revised the manuscript for } \\
\text { intellectual content }\end{array}$ \\
\hline $\begin{array}{l}\text { Fiore } \\
\text { Manganelli, } \\
\text { MD }\end{array}$ & $\begin{array}{l}\text { Department of } \\
\text { Neuroscience, } \\
\text { Reproductive and } \\
\text { Odontostomatology } \\
\text { Science, University of } \\
\text { Naples Federico II, } \\
\text { Italy }\end{array}$ & $\begin{array}{l}\text { Design and conceptualized } \\
\text { study and revised the } \\
\text { manuscript for intellectual } \\
\text { content }\end{array}$ \\
\hline
\end{tabular}

\section{References}

1. Cortese A, Simone R, Sullivan R, et al. Biallelic expansion of an intronic repeat in RFC1 is a common cause of late-onset ataxia [published correction appears in Nat Genet. 2019 May;51(5):920]. Nat Genet 2019;51:649-658.

2. Cortese A, Tozza S, Yau WY, et al. Cerebellar ataxia, neuropathy, vestibular areflexia syndrome due to RFC1 repeat expansion. Brain 2020;143:480-490. 


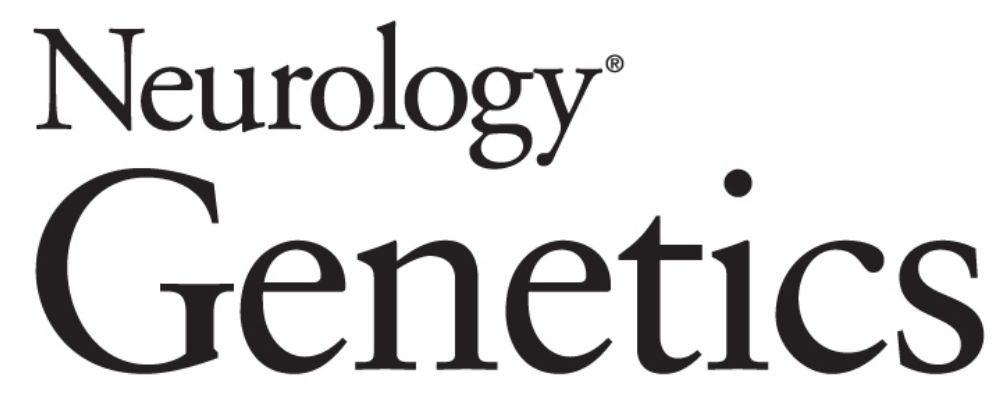

\section{Bedside Head Impulse Test: A Useful Tool for Patients With Sensory Ataxia \\ Stefano Tozza, Andrea Cortese, Aniello Iovino, et al. \\ Neurol Genet 2021;7; \\ DOI 10.1212/NXG.0000000000000541}

This information is current as of December 21, 2020

\section{Updated Information \& Services}

References

Subspecialty Collections

Permissions \& Licensing

Reprints including high resolution figures, can be found at: http://ng.neurology.org/content/7/1/e541.full.html

This article cites 2 articles, 0 of which you can access for free at: http://ng.neurology.org/content/7/1/e541.full.html\#\#ref-list-1

This article, along with others on similar topics, appears in the following collection(s):

All Genetics

http://ng.neurology.org//cgi/collection/all_genetics

All Neurotology

http://ng.neurology.org//cgi/collection/all_neurotology

Clinical neurology examination

http://ng.neurology.org//cgi/collection/clinical_neurology_examination

\section{Peripheral neuropathy}

http://ng.neurology.org//cgi/collection/peripheral_neuropathy

Information about reproducing this article in parts (figures,tables) or in its entirety can be found online at:

http://ng.neurology.org/misc/about.xhtml\#permissions

Information about ordering reprints can be found online: http://ng.neurology.org/misc/addir.xhtml\#reprintsus

Neurol Genet is an official journal of the American Academy of Neurology. Published since April 2015, it is an open-access, online-only, continuous publication journal. Copyright Copyright $\odot 2020$ The Author(s). Published by Wolters Kluwer Health, Inc. on behalf of the American Academy of Neurology.. All rights reserved. Online ISSN: 2376-7839.

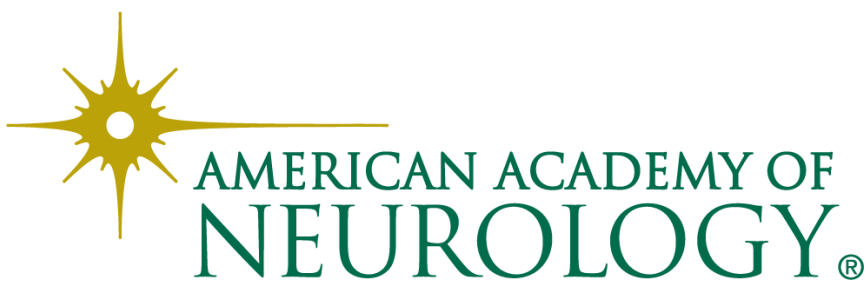

